\title{
Kemampuan Berpikir Kritis Matematis Siswa Madrasah Aliyah Kelas 12 pada Materi Statistika
}

\author{
Siti Muthmainah Darmawan*, Attin Warmi \\ Universitas Singaperbangsa Karawang, Indonesia \\ *Coresponding Author: 1810631050097@student.unsika.ac.id
}

Article History:

Received 2022-01-27

Revised 2022-02-23

Accepted 2022-03-03

DOI:

10.31949/educatio.v8i1.1980

\begin{abstract}
The ability to think critically is one of the abilities that must be possessed by the students to be able to solve simple and complex problems in their daily lives. Critical thinking skills of students mathematical is still relatively low. The purpose of this research was to describe the mathematical critical thinking skills $M A$ students of class 12 to solve the problems on the material of statistics. This research is a qualitative descriptive study, using the subject class XII students as much as 3 students that are grouped into categories of high, medium, and low. This research was conducted at the MA Nihayatul Purwasari School on November 2, 2021. The research samples were taken by using purpossive sampling. The data obtained with the test method using the instrument to test the ability of critical thinking mathematically. Then, data were analyzed based on the indicators of critical thinking skills. The results of the research are (1) the critical thinking skills of students 'mathematical category bigh've been able to do all the stages on the indicators of critical thinking skills, except the evaluation stage; (2) the critical thinking skills of students' mathematical category medium are already able to do almost all the stages on the indicators of critical thinking skills; (3) the critical thinking skills mathematical students categorized as low can only do stage clarification on indicators of critical thinking skills.
\end{abstract}

Keywords: analysis; critical thinking; statistics

\begin{abstract}
Abstrak
Kemampuan berpikir kritis merupakan salah satu kemampuan yang harus dimiliki oleh siswa untuk dapat memecahkan masalah sederhana dan kompleks di dalam kehidupan sehari-hari mereka. Kemampuan berpikir kritis matematis siswa masih tergolong rendah. Tujuan penelitian ini untuk mendeskripsikan kemampuan berpikir kritis matematis siswa MA kelas 12 dalam menyelesaikan soal pada materi statistika. Penelitian ini adalah penelitian deskriptif kualitatif, dengan menggunakan subjek siswa kelas XII sebanyak 3 orang siswa yang dikelompokan ke kategori tinggi, sedang, dan rendah. Penelitian ini dilaksanakan di Sekolah MA Nihayatul Purwasari pada tanggal 2 November 2021. Pemilihan subjek dilakukan dengan cara purpossive sampling. Pengambilan data diperoleh dengan metode tes menggunakan instrumen tes kemampuan berpikir kritis matematis. Kemudian, data tersebut dianalisis berdasarkan indikator kemampuan berpikir kritis. Hasil penelitiannya adalah (1) kemampuan berpikir kritis matematis siswa berkategori tinggi sudah dapat melakukan semua tahapan pada indikator kemampuan berpikir kritis, kecuali tahap evaluasi; (2) kemampuan berpikir kritis matematis siswa berkategori sedang sudah dapat melakukan hampir semua tahapan pada indikator kemampuan berpikir kritis; (3) kemampuan berpikir kritis matematis siswa berkategori rendah hanya dapat melakukan tahap klarifikasi pada indikator kemampuan berpikir kritis.
\end{abstract}

Kata Kunci: analisis; kemampuan berpikir kritis; statistika

\section{PENDAHULUAN}

Pendidikan adalah suatu usaha terencana, dalam proses belajar serta penciptaan suasana belajar agar siswa dapat mengembangkan potensi dirinya untuk menjadi kompeten dalam kemampuan yang dipelajarinya (Yunita et al., 2018). Pendidikan merupakan salah satu hal yang penting dalam kehidupan manusia. Tempat di 
mana orang tumbuh dan berkembang sebagai individu yang sempurna melalui pendidikan. Dengan adanya pendidikan, manusia dapat mengembangkan pengetahuan dan meningkatkan kualitas hidup. Oleh karena itu, pendidikan sangat dibutuhkan untuk meningkatkan kualitas sumber daya manusia. Salah satu upaya pengembangan sumber daya manusia adalah pembelajaran matematika (Hasanah \& Haerudin, 2021).

Matematika merupakan suatu ilmu yang dianggap penting serta tidak dapat dipisahkan dalam pendidikan dan kehidupan sehari-hari guna meningkatkan kualitas sumber daya manusia (Rahma et al., 2017; Wijaya et al., 2018). Dari perspektif klasifikasi ilmu-ilmu alam, matematika termasuk di antara ilmu-ilmu eksakta yang membutuhkan lebih banyak keterampilan berpikir. Matematika dapat membentuk sifat berpikir siswa menjadi manusia yang berpikir kritis, kreatif, dan mandiri serta memiliki tingkatan dan aturan yang jelas (Hasanah \& Haerudin, 2021).

Purwanto (Kharisma, 2018) menyatakan bahwa berpikir merupakan salah satu sifat yang dimiliki manusia untuk menghasilkan sesuatu yang terarah untuk menuju tujuan tertentu. Menurut Trianto (Purmawidyani, 2017) berpikir adalah suatu kemampuan yang dimiliki sesorang untuk menganalisis, mengkritik, dan mencapai kesimpulan berdasarkan pemeriksaan yang cermat. Kemampuan berpikir yang harus dimiliki oleh siswa salah satu adalah kemampuan berpikir kritis (Tresnawati et al., 2017). Berpikir kritis adalah tentang berpikir secara mendalam tentang suatu masalah, tetap terbuka terhadap pendekatan dan perspektif yang berbeda, tidak dapat dengan mudah mempercayai informasi dari sumber yang berbeda (lisan atau tertulis), dan hanya menerima ide (Kodu et al., 2019). Menurut Ennis (Sari et al., 2016) menyatakan bahwa berpikir kritis merupakan berpikir logis dan reflektif yang menfokuskan pada suatu keputusan yang akan dilakukan. Pada matematika berpikir kritis yang dimaksud diantaranya berpikir yang mengkaji, menanyakan, menghubungkan, dan mengevaluasi semua aspek dari suatu situasi atau masalah (Zetriuslita et al., 2016). Berpikir kritis adalah berpikir logis dan reflektif, dengan menekankan pada pengambilan keputusan tentang apa yang harus dipercaya dan apa yang harus dilakukan. Dari beberapa pengertian berpikir kritis di atas, dapat disimpulkan bahwa berpikir kritis adalah sebuah cara berpikir lebih dalam dimana untuk mendapatkan sebuah informasi tidak dengan mentah-mentah, tetapi harus jelas dapat dipercaya, logis, dan dapat menghubungkan ke semua aspek dari suatu masalah sehingga dapat ditarik kesimpulan yang tepat.

Jacob \& Sam (Nugroho, 2017) menyatakan bahwa tahapan berpikir kritis matematis dapat dibagi kedalam empat tahapan, diantaranya: (1) Tahap klarifikasi; Tahapan ini adalah tahap mengidentifikasi, klarifikasi, serta mendefinisikan masalah. Indikatornya adalah menjelaskan pokok-pokok masalah secara rinci. Kegiatan yang dilakukan adalah siswa secara akurat dan jelas dapat menentukan informasi apa yang diketahui dengan tepat. (2) Tahap asesmen; Tahap ini adalah tahap mengevaluasi aspek-aspek seperti pengambilan keputusan pada suatu situasi, mengemukakan fakta yang ada disertai argumen atau mengaitkan masalah dengan masalah lain. Pada tahap ini berbagai fakta digunakan untuk mendukung atau menyangkal. Indikatornya yaitu memberi alasan untuk menarik kesimpulan yang benar. Kegiatan yang dilakukan adalah siswa mampu mengidentifikasi ide/konsep yang digunakan untuk memecahkan masalah. (3) Tahap inferensi; tahap menunjukkan hubungan antara beberapa ide, menarik kesimpulan dengan tepat, serta menggeneralisasikannya. Indikatornya yaitu membuat kesimpulan yang logis dan jelas. Kegiatan yang dilakukan adalah siswa dapat menarik kesimpulan dengan tepat dari masalah. (4) Tahap strategi; Tahapan ini merupakan tahap mengajukan, mengevaluasi berbagai tindakan, menjelaskan kemungkinan tindakan, dan memprediksi hasil dari tindakan yang dilakukan. Indikatornya yaitu menyelesaikan masalah dengan beragam alternatif penyelesaian secara konsisten dan benar berdasarkan konsep. Kegiatan yang dilakukan siswa adalah dapat mengerjakan soal menggunakan berbagai alternatif penyelesaian dengan runtut dan benar dalam menyelesaian soal.

Berpikir kritis diperlukan untuk menyelidiki keaslian informasi dan memutuskan apakah informasi yang didapat bisa diterima atau tidak. Oleh sebab itu, dengan memiliki kemampuan berpikir kritis akan tidak mudah untuk mempercayai informasi yang tidak benar dan pada setiap individu tidak terburu-buru untuk mengambil keputusan (Hidayanti et al., 2016). Keberhasilan siswa dalam memecahkan suatu masalah pada soal matematika bukan hanya dipengaruhi oleh kemampuan mengajar guru, tetapi juga dipengaruhi dengan kemampuan belajar siswa yang sangat baik dan kemampuan berpikir kritis siswa yang baik (Rahma et al., 
2017). Peraturan Menteri Pendidikan No. 22 (2006) menyatakan bahwa kemampuan berpikir kritis harus dimiliki siswa untuk mengolah dan menggunakan informasi untuk dapat bertahan hidup didalam situasi yang berubah-ubah, tidak pasti serta kompetitif (Rahma et al., 2017).

Gueldenzoph dan Snyder (Fithriyah et al., 2016) menyatakan bahwa berpikir kritis penting karena sesorang yang berpikir kritis akan secara otomatis dapat memecahkan masalah sederhana dan kompleks di dalam kehidupan sehari-hari mereka. Berdasarkan beberapa pendapat di atas dapat disimpulkan bahwa memiliki keammapuan berpikir kritis sangatlah penting untuk dapat mengelola informasi serta tidak mudah percaya dengan informasi yang tidak benar agar dapat bertahan hidup dalam berbagai situasi.

Berdasarkan pengamatan peneliti pada saat mengajar disalah satu sekolah Karawang, masih banyak siswa yang mengalami kesulitan dalam menyelesaikan soal matematika. Siswa banyak yang masih sulit dalam memahami permasalahan yang diberikan, serta siswa tidak mampu menggunakan rumus atau konsep yang tepat untuk menyelesaikan masalah. Senada pada hasil penelitian Kodu (2019) yang menyatakan bahwa kemampuan berpikir kritis siswa berkategori rendah masih banyak yaitu 78,26\% dari siswa yang ditelitinya. Salah satu penyebabnya yaitu siswa kurang mampu dalam membuat kesimpulan dan menyelesaikan soal matematika dengan menggunakan lebih dari satu metode.

Berdasarkan penelitian yang dilakukan Hidayanti (2016) juga menyatakan bahwa kemampuan berpikir kritis siswa masih tergolong rendah. Hal tersebut terjadi karena pada masing-masing indikator kemampuan berpikir kritis siswa belum terpenuhi yaitu masih di bawah 50\%. Indikator yang terlihat masih sangat rendah khususnya terdapat pada indikator analisis, evaluasi, dan inferensi analisis. Sejalan dengan penelitian yang dilakukan Kharisma (2018) yang menyimpulkan bahwa kemampuan berpikir kritis matematis siswa SMK ratarata masih tergolong rendah pada hampir semua indikator berpikir kritis. Pada penelitian Widiantari (2016) menyimpulkan bahwa rata-rata kemampuan berpikir kritis siswa masih tergolong rendah yaitu sebesar 55,04, dengan indikator tertinggi adalah indikator menganalisis pertanyaan sebesar $82,99 \%$ dan indikator terendah adalah indikator mengidentifikasi asumsi sebesar 0\%. Sejalan dengan penyataan bahwa siswa masih mengalami kesulitan terhadap beberapa indikator dalam menganalisis, mengevaluasi, dan membuat kesimpulan dalam mengerjakan soal-soal berpikir kritis matematis (Fatmawati et al., 2014; Noordyana, 2016). Hal tersebut terjadi karena pemahaman konsep materi yang dimiliki siswa masih kurang, siswa terlalu cepat dalam menarik kesimpulan, serta siswa tidak terbiasa juga dalam penyajian pembelajaran aktif yang menigkatkan kemampuan berpikir siswa. Perbedaan penelitian ini dengan penelitian-penelitian terdahulu yaitu diantaranya terdapat beberapa dari penelitian terdahulu dalam mengukur kemampuan berpikir kritis siswa dengan menggunakan tingkat kesetaraan dan materi yang berbeda.

Berdasarkan latar belakang masalah yang telah dipaparkan di atas, maka rumusan masalah dalam penelitian ini adalah "Bagaimana deskripsi kemampuan berpikir kritis matematis siswa MA kelas 12 dalam menyelesaikan soal pada materi statistika?". Penelitian ini bertujuan untuk mendeskripsikan kemampuan berpikir kritis matematis siswa MA kelas 12 dalam menyelesaikan soal pada materi statistika.

\section{METODE PENELITIAN}

Jenis penelitian yang digunakan adalah penelitian deskriptif kualitatif. Penelitian kualitatif dilakukan karena penemuan yang dihasilkan tidak dapat menggunakan cara dari kuantifikasi yang bersifat deskriptif (Warniasih et al., 2019). Adapun tujuan penelitian ini yaitu untuk mengetahui kemampuan berpikir kritis matematis siswa dalam menyelesaikan soal pada materi statistika.

Penelitian ini dilaksanakan di Sekolah MA Nihayatul Purwasari. Pelaksanaan penelitian ini dilakukan pada tanggal 2 November 2021. Subjek dalam penelitian ini adalah siswa kelas 12 IPA yang berjumlah 3 orang siswa. Instrumen soal yang digunakan adalah soal tes kemampuan berpikir kritis yang berjumlah 2 soal. Instrumen soal tersebut diadopsi dari tesis Rachmawati (2019) dan sudah di uji reliabilitas, uji validitas, dan sebagainya. Teknik analisis data yang digunakan pada penelitian ini meliputi: reduksi data, penyajian data, dan penarikan kesimpulan Hasil data yang diperoleh yaitu berupa data hasil tes soal kemampuan berpikir ktitis. Teknik pengumpulan data yang dilakukan pada penelitian ini yaitu dengan observasi dan dokumentasi. Penelitian ini diawali dengan meberi soal tes kemampuan berpikir ktitis kepada 30 orang siswa dari kelas 12 
IPA secara purpossive sampling, lalu dikelompokkan ke dalam tiga kategori, yaitu tinggi, sedang, dan rendah. Kemudian, dipilih 3 orang secara acak untuk dianalisis. Klasifikasi kategori pada subjek penelitian berdasarkan Tabel 1. (Anggraeni \& Widayanti, 2019).

Tabel 1. Klasifikasi Kategori

\begin{tabular}{cc}
\hline Rentang & Kategori \\
\hline $\mathrm{x} \geq$ (nilai rata-rata + standar deviasi) & Tinggi \\
(nilai rata-rata - standar deviasi) $<\mathrm{x}<$ (nilai rata-rata + & Sedang \\
standar deviasi) & Rendah \\
\hline
\end{tabular}

Keterangan : $\mathrm{x}$ adalah nilai soal tes.

\section{HASIL DAN PEMBAHASAN}

Berdasarkan data yang diperoleh yaitu data berupa nilai siswa yang diperoleh pada tes dalam menyelesaikan soal kemampuan berpikir kritis, maka diperoleh hasil sebagaimana disajikan pada Tabel 2.

Tabel 2. Data Hasil Tes

\begin{tabular}{cccc}
\hline Jumlah Siswa & Nilai Maksimum & Nilai Minimum & Rata-rata \\
\hline 30 & 71 & 25 & 48,9 \\
\hline
\end{tabular}

Berdasarkan Tabel 2. hasil penelitian dari jumlah siswa yang mengerjakan soal tes kemampuan berpikir kritis yaitu 30 siswa telah diperoleh nilai maksimum siswa adalah 71 , nilai minimum siswa adalah 25 , dan nilai rata-rata siswa adalah 48,9. Selanjutnya, data dikelompokkan ke dalam kategori yang ada pada tabel 3 di bawah ini. Berikut hasil soal tes dipaparkan dalam klasifikasi kategori yang disajikan pada Tabel 3.

Tabel 3. Klasifikasi Kategori Dari Hasil Soal Tes

\begin{tabular}{lccc}
\hline Rentang & Kategori & Jumlah siswa & Persentase Siswa \\
\hline $\mathrm{x} \geq 60,799$ & Tinggi & 5 & $17 \%$ \\
$37,067<\mathrm{x}<60,799$ & Sedang & 18 & $60 \%$ \\
$\mathrm{x} \leq 37,067$ & Rendah & 7 & $23 \%$ \\
\hline
\end{tabular}

Berdasarkan klasifikasi kategori dari Tabel 3., diperoleh siswa yang berkategori tinggi sebanyak 5 siswa dengan persentasenya yaitu 17\%, siswa yang berkategori sedang sebanyak 18 siswa dengan persentasenya yaitu $60 \%$, dan siswa berkategori rendah adalah sebanyak 7 orang dengan persentasenya yaitu $23 \%$. Berikut hasil penilaian pada subjek penelitian yang dipilih secara purposive sampling sebagaimana disajikan pada Tabel 4.

Tabel 4. Hasil Penilaian Subjek Penelitian

\begin{tabular}{lccc}
\hline No & Kode Siswa & Nilai & Persentase Siswa \\
\hline 1 & S1 & 68 & Tinggi \\
2 & S2 & 58 & Sedang \\
3 & S3 & 30 & Rendah \\
\hline
\end{tabular}

Berdasarkan hasil lembar jawaban siswa untuk masing-masing kategori dideskripsikan sebagai berikut: 1. Analisis kemampuan berpikir kritis pada siswa kategori tinggi

Pada gambar 1, berdasarkan indikator kemampuan berpikir kritis matematis siswa dapat dianalisis bahwa siswa berkategori tinggi yaitu S1 pada No 1 sebagai berikut: (1) Tahap klarifikasi, terlihat bahwa S1 sudah dapat menentukan informasi apa saja yang diketahui di dalam soal dengan jelas dan tepat; (2) Tahap asesmen, S1 sudah dapat melakukan tahap ini. Dilihat dari S1 yang dapat menjawab point a dengan tepat. Untuk mencari keseluruhan jawaban di point a harus dapat menentukan ide/konsep sehingga dapat memecahkan masalah yang ada dalam menentukan informasi di soal tersebut. 


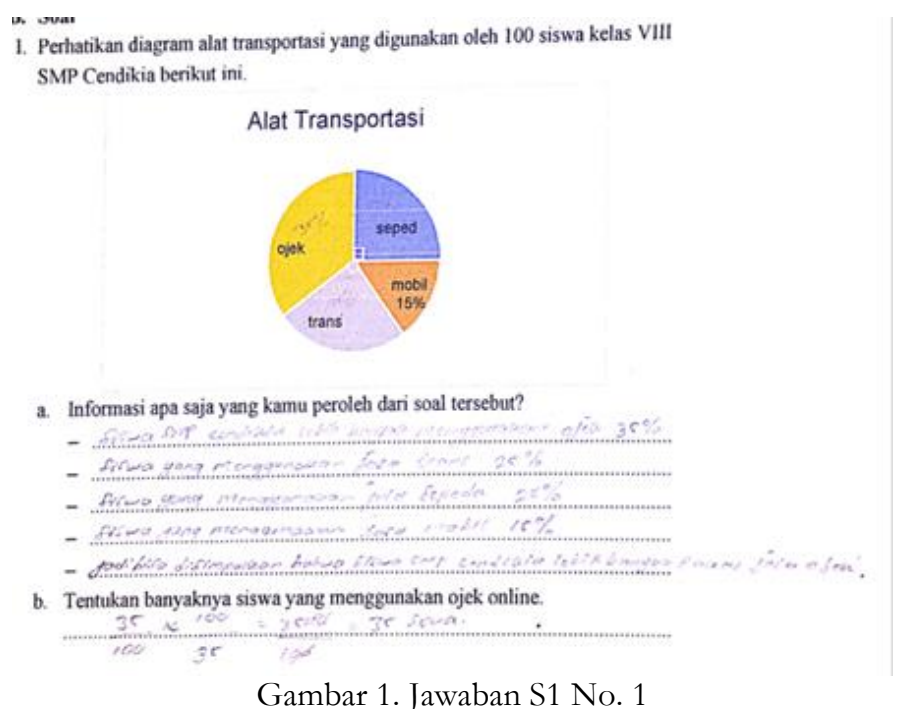

Terlihat juga pada jawaban point b, S1 dapat mengemukakan fakta dari jawaban di point a dan menghubungkannya sehingga dapat menyelesaiakan masalah tersebut; (3) Tahap inferensi, S1 sudah dapat menarik kesimpulan dengan baik; (4) Tahap strategi, terlihat pada point b, bahwa S1 dapat melakukan suatu tindakan yang harus dilakukan dalam menyelesaikan masalah tersebut dengan benar. Hanya saja masih kurang teliti dalam penulisannya. Sehingga dapat disimpulkan bahwa S1 dalam menjawab soal No 2 bahwa siswa yang berkategori tinggi sudah dapat melakukan semua tahapan dalam indikator kemampuan berpikir kritis matematis.

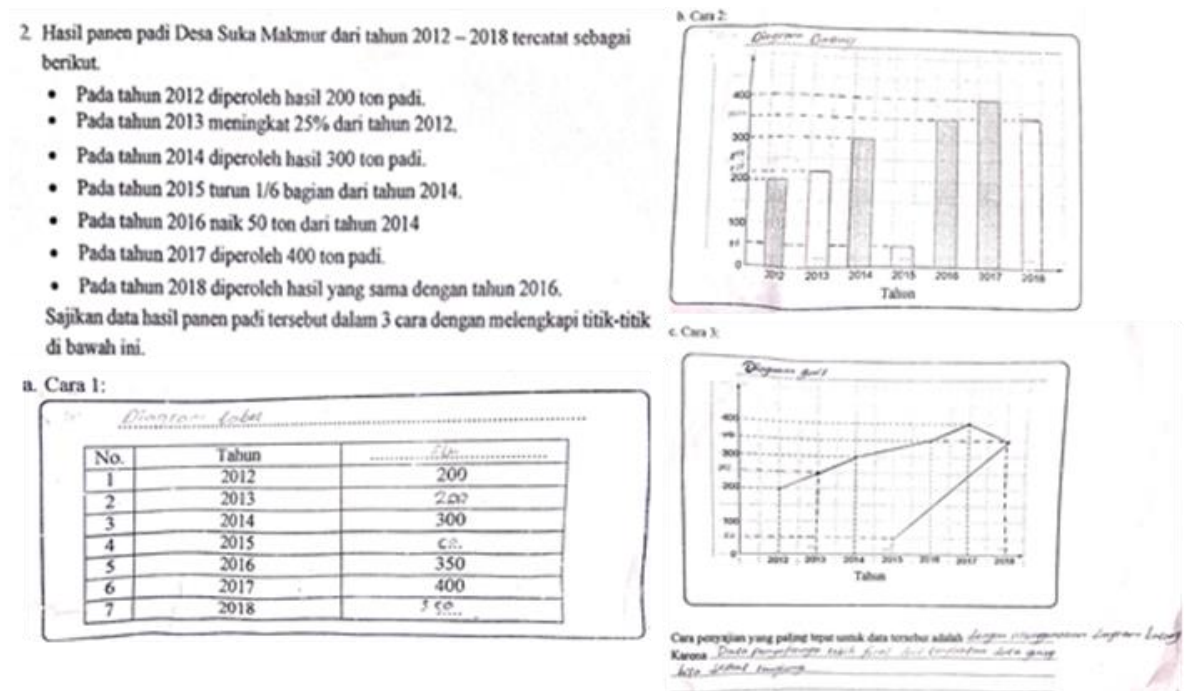

Gambar 2. Jawaban S1 No. 2

Pada gambar 2, berdasarkan indikator kemampuan berpikir kritis matematis siswa dapat dianalisis bahwa jawaban S1 pada No 2 sebagai berikut: (1) Tahap klarifikasi, terlihat bahwa S1 sudah dapat menentukan informasi apa saja yang diketahui di dalam soal tetapi masih kurang tepat; (2) Tahap asesmen, S1 sudah dapat melakukan tahap ini. Dilihat pdari jawaban di point a, b, dan c yang terisi semua. Untuk dapat mengisi point a, b, dan c S1 harus dapat menentukan ide/konsep, mengemukakan fakta dari informasi yang diketahu dan menghubungkannya sehingga dapat menyelesaiakan masalah tersebut; (3) Tahap inferensi, S1 sudah dapat menarik kesimpulan dengan baik; (4) Tahap strategi, S1 dapat mengajukan tindakan yang lebih baik dilakukan berikut alasannya, tetapi masih kurang tepat. Maka, dapat dikatakan S1 belum dapat mengevaluasi berbagai tindakan yang ada yaitu dengan menggunakan diagram tabel, diagram batang, atau diagram garis. Sehingga dapat disimpulkan bahwa S1 dalam menjawab soal No 2 sudah dapat melakukan semua tahapan dalam indikator kemampuan berpikir kritis matematis, kecuali tahap strategi.

2. Analisis kemampuan berpikir kritis pada siswa kategori sedang 


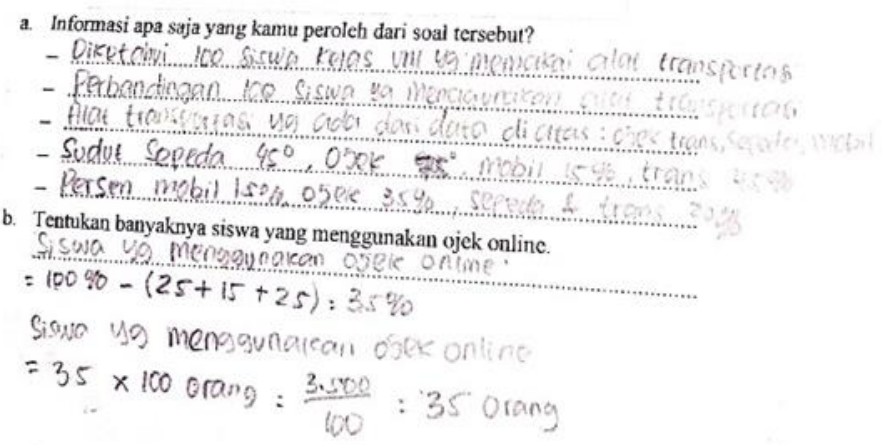

Gambar 3. Jawaban S2 No. 1

Pada gambar 3, berdasarkan indikator kemampuan berpikir kritis matematis siswa dapat dianalisis bahwa siswa berkategori sedang yaitu S2 pada No 1 sebagai berikut: (1) Tahap klarifikasi, terlihat bahwa S2 sudah dapat menentukan informasi apa saja yang diketahui di dalam soal, tetapi masih kurang tepat. Terlihat dijawaban point b, S2 masih salah dalam menentukan berapa persen yang menggunakan alat transportasi sepeda dan transjogja; (2) Tahap asesmen, S2 dapat menghubungkan beberapa ide/konsep untuk menjawab permasalahan soal tersebut. Dilihat dari penyelesaian S2 yang menggunakan konsep derajat dan persen dalam satu lingkaran penuh, serta dapat menggunakan informasi yang ada dipoint a untuk menjawab point b; (3) Tahap inferensi, S2 tidak membuat suatu kesimpulan dari soal yang diberikan; (4) Tahap strategi, terlihat pada jawaban point b bahwa S2 dapat menuliskan tindakan/strategi untuk menyelesaikan masalah tersebut dengan runtut dan benar. Sehingga dapat disimpulkan bahwa S2 dalam menjawab soal No 1 sudah dapat melakukan hampir semua tahapan dalam indikator kemampuan berpikir kritis matematis dengan baik. Pada indikator kemampuan berpikir kritis matematis siswa berkategori sedang hanya tidak melakukan tahap inferensi

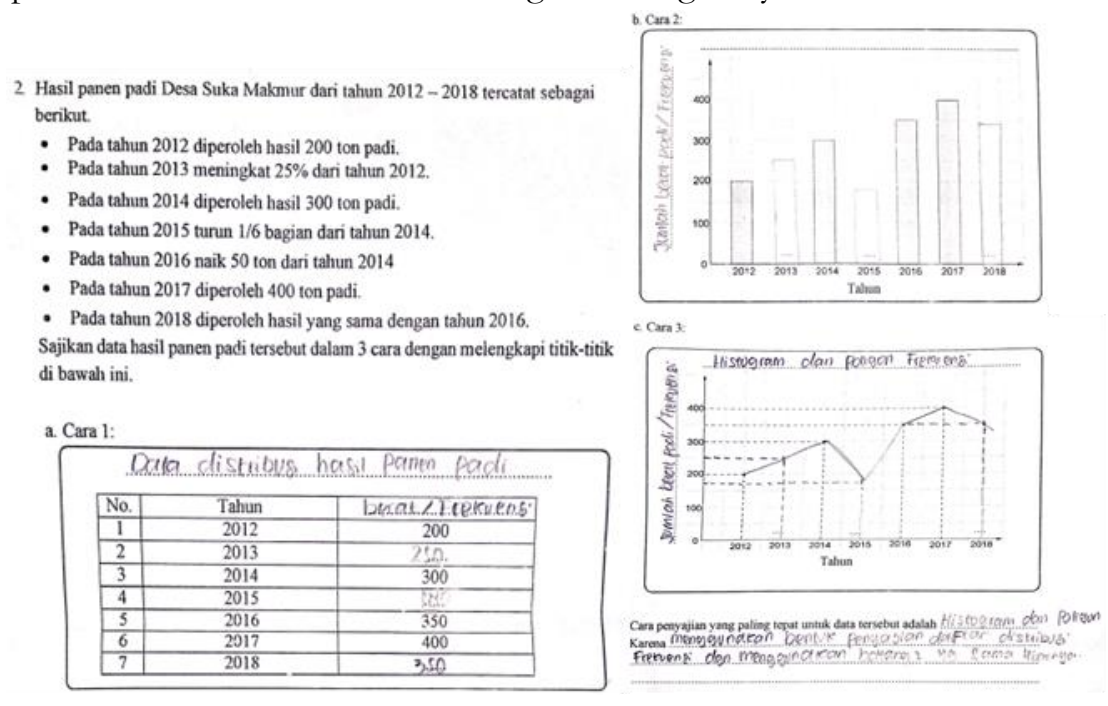

Gambar 4. Jawaban S2 No. 2

Pada gambar 4, berdasarkan indikator kemampuan berpikir kritis matematis siswa dapat dianalisis bahwa jawaban S2 pada No 2 sebagai berikut: (1) Tahap klarifikasi, terlihat bahwa S2 sudah dapat menentukan informasi apa saja yang diketahui di dalam soal tetapi masih kurang tepat; (2) Tahap asesmen, dilihat dari jawabanya yang terisi semua, walaupun masih ada beberapa yang kurang tepat. S2 dapat menentukan ide/konsep, mengemukakan fakta dari informasi yang diketahui dan menghubungkannya sehingga dapat menyelesaiakan masalah tersebut; (3) Tahap inferensi, S2 sudah dapat menarik kesimpulan dengan baik; (4) Tahap strategi, S2 dapat mengajukan dan memilih tindakan yang lebih baik dilakukan dengan tepat, tetapi alasan yang diberikan masih kurang tepat. Sehingga dapat disimpulkan bahwa S2 dalam menjawab soal No 2 sudah dapat melakukan semua tahapan dalam indikator kemampuan berpikir kritis matematis, kecuali tahap strategi. 
3. Analisis kemampuan berpikir kritis pada siswa kategori rendah

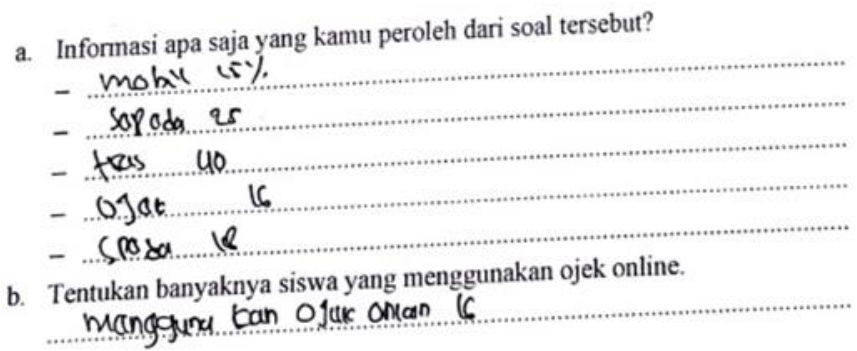

Gambar 5. Jawaban S3 No. 1

Pada gambar 5, berdasarkan indikator kemampuan berpikir kritis matematis siswa dapat dianalisis bahwa siswa berkategori rendah yaitu S3 sebagai berikut: (1) Tahap klarifikasi, terlihat bahwa S3 sudah dapat menuliskan informasi apa saja yang diketahui di dalam soal, tetapi tidak dapat menentukan informasi yang diketahui di dalam soal. Terlihat dijawaban point a yang hampir salah semua dan yang benar hanya yang secara langsung diberitahu di dalam soal yaitu mobil sebanyak 15\%; (2) Tahap asesmen, S2 tidak dapat menghubungkan beberapa ide/konsep untuk menjawab permasalahan soal tersebut. Dilihat dari penyelesaian S3 di point a dan point b yang salah semua. (3) Tahap inferensi, S2 juga tidak membuat suatu kesimpulan dalam menyelesaikan soal; (4) Tahap strategi, terlihat pada jawaban point a dan point b bahwa S2 tidak menuliskan strategi untuk menyelesaikan soal yang diberikan.

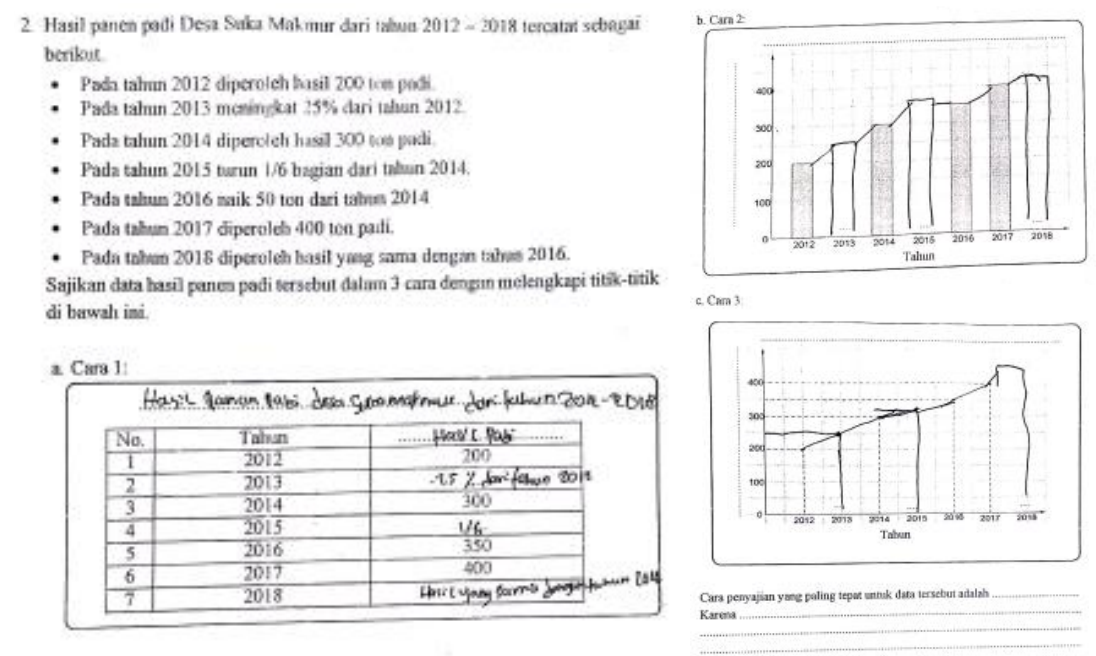

Gambar 6. Jawaban S3 No. 2

Pada gambar 6, berdasarkan indikator kemampuan berpikir kritis matematis siswa dapat dianalisis bahwa jawaban S3 pada No 2 sebagai berikut: (1) Tahap klarifikasi, terlihat bahwa S3 sudah dapat menuliskan informasi apa saja yang diketahui di dalam soal tetapi masih kurang tepat; (2) Tahap asesmen, S3 belum dapat menentukan ide/konsep, mengemukakan fakta dari informasi yang diketahui dan menghubungkannya sehingga dapat menyelesaiakan masalah tersebut. Hal tersebut dapat dilihat dari jawaban di point a yang salah dan tidak bisa menghubungkannya untuk menyelasaikan masalah di point a dan point b; (3) Tahap inferensi, S3 tidak menarik kesimpulan dalam menyelesaikan soal; (4) Tahap strategi, S3 tidak dapat mengajukan dan memilih tindakan yang lebih baik dilakukan dengan tepat. Hal tersebut dilihat dari S3 tidak menuliskan cara penyajian data yang tepat dan disertakan alasannya. Sehingga dapat disimpulkan bahwa S3 dalam menjawab soal No 2 belum dapat melakukan semua tahapan dalam indikator kemampuan berpikir kritis matematis. Tahapan yang hanya dapat dilakukan oleh S3 adalah tahap klarifikasi. 
Berdasarkan analisis data yang telah dilakukan didapat bahwa kemampuan berpikir krtisi matematis siswa pada materi statistika masih kurang dan tergolong rendah. Hal ini dapat dilihat dari jawaban siswa yang tidak ada yang dapat melakukan tahapan strategi dengan baik dan tepat. Sejalan dengan penelitian (Snyder et al., 2008; Peter, 2012) yang menyatakan bahwa kurangnya latihan dalam mengevaluasi ini mengakibatkan kemampuan berpikir kritis siswa rendah disebabkan karena masih kurangnya latihan dalam mengevaluasi dari suatu permasalahan soal. Pada tahap strategi siswa belum dapat mengevaluasi berbagai tindakan serta memberi alasan yang tepat daan logis mengapa dipilih tindakan tersebut.

Siswa yang berkategori tinggi dapat melakukan 3 dari 4 tahapan dalam indikator kemampuan berpikir kritis matematis dengan baik. Tahapan yang tidak dapat dilakukan oleh siswa berkategori tinggi yaitu pada tahap strategi. Hal ini terjadi karena pemberian latihan soal selama pembelajaran merupakan soal rutin dengan kata lain latihan soal yang diberikan tidak meningkatkan kemampuan berpikir kritis siswa. Siswa juga masih mengalami kesulitan dalam menerapkan pengetahuan dasar/konsep yang telah dimilikinya. Menurut Carson (Hidayanti et al., 2016) mengatakan bahwa walaupun siswa memiliki pengetahuan konsep pada suatu materi tetapi siswa belum tentu dapat menerapkannya dalam menyelesaikan soal yang diberikan. Oleh sebab itu, siswa diharapkan untuk memperbanyak latihan soal dengan menerapkan konsep yang dimiliki siswa. Sejalan dengan penelitian (Dewi et al., 2019) menyatakan bahwa kesalahan pada saat proses pengerjaan soal karena latihan soal yang diberikan selama ini tidak membuat siswa untuk meningkatkan kemampuan berpikir kritis.

Siswa yang berkategori sedang dapat melakukan hampir semua tahapan dalam indikator kemampuan berpikir kritis matematis dengan baik Tahapan yang tidak dapat dilakukan oleh siswa berkategori sedang yaitu pada tahap inferensi dan tahap strategi. Hal ini terjadi karena kurangnya pemahaman siswa dalam menentukan rumus awal serta menyelesaikan masalah dan kurang mampu menarik kesimpulan dengan jelas. Sejalan dengan penelitian (Dewi et al., 2019) yang menyatakan bahwa pemahaman siswa masih kurang dalam menentukan ide/konsep awal untuk menyelesaikan masalah.

Sedangkan siswa yang berkategori rendah tidak dapat melakukan hampir semua tahapan dalam indikator kemampuan berpikir kritis matematis dengan baik. Siswa yang berkategori rendah hanya dapat melakukan tahap klarifikasi dalam indikator kemampuan berpikir kritis. Hal ini dikarenakan siswa masih belum memahami konsep materi dengan baik sehingga jawabannya salah. Seperti yang dijelaskan oleh Snyder dalam penelitian (Sari et al., 2016) menyatakan bahwa kurangnya pengetahuan dan pemahaman konsep yang sedikit akan dapat menghambat siswa dalam berpikir kritis. Sejalan juga dengan penelitian (Fatmawati et al., 2014) menyatakan bahwa siswa berkategori rendah hanya terbatas dalam kemampuan menghafal tetapi tidak dapat memahami konsep secara utuh. Berdasarkan hasil penelitian dan penelitian-penelitian yang relevan di atas dapat disimpulkan bahwa rendahnya kemampuan berpikir kritis matematis siswa disebabkan oleh kurangnya pengetahun dasar dan pemahaman konsep materi; kurangnya penggunaan penerapan pengetahuan dasar pada saat latihan soal; dan kurang perbanyak latihan soal non rutin.

\section{KESIMPULAN}

Kemampuan berpikir kritis matematis siswa yang dilihat dari 4 tahapan yaitu, tahap klarifikasi, tahap asesmen, tahap inferensi, dan tahap strategi. Berdasarkan hasil dan pembahasan penelitian yang telah dijabarkan, dapat disimpulkan bahwa kemampuan berpikir matematis siswa kelas 12 masih tergolong rendah. Hal tersebut ditunjukkan dengan hasil tes kemampuan berpikir kritis matematis siswa. Siswa yang berkategori tinggi sebanyak 5 siswa dengan persentasenya yaitu 17\%, siswa yang berkategori sedang sebanyak 18 siswa dengan persentasenya yaitu $60 \%$, dan siswa berkategori rendah adalah sebanyak 7 orang dengan persentasenya yaitu $23 \%$. Siswa yang berkategori tinggi dapat melakukan semua tahapan dalam indikator kemampuan berpikir kritis matematis dengan baik, kecuali tahap strategi. Siswa yang berkategori sedang dapat melakukan hampir semua tahapan dalam indikator kemampuan berpikir kritis matematis dengan baik. Tahapan yang tidak dilakukan yaitu tahap strategi dan tahap inferensi. Sedangkan siswa yang berkategori rendah hanya dapat melakukan tahap klarifikasi dalam indikator kemampuan berpikir kritis matematis dengan 
baik. Hal tersebut dikarenakan siswa yang masih belum memahami konsep materi dengan baik serta kurang perbanyak latihan soal non rutin.

\section{DAFTAR PUSTAKA}

Dewi, D. P., Mediyani, D., Hidayat, W., Rohaeti, E. E., \& Wijaya, T. T. (2019). Analisis Kemampuan Berpikir Kritis Matematis Siswa Smp Pada Materi Lingkaran Dan Bangun Ruang Sisi Datar. JPMI Jurnal Pembelajaran Matematika Inovatif), 2(6), 371. https://doi.org/10.22460/jpmi.v2i6.p371-378

Fatmawati, H., Mardiyana, \& Triyanto. (2014). Analisis Berpikir Kritis Siswa Dalam Pemecahan Masalah Matematika Berdasarkan Polya pada Pokok Bahasan Persamaan Kuadrat (Penelitian pada Siswa Kelas X SMK Mubammadiyah 1 Sragen Tabun Pelajaran 2013/2014). 2(9), 899-910. https://doi.org/10.31227/osf.io/wsza9

Fithriyah, I., Sa'dijah, C., \& Sisworo. (2016). Analisis Kemampuan Berpikir Kritis. Prosiding Konferensi Nasional Penelitian Matematika Dan Pembelajarannya, Knpmp I, 580-590.

Hasanah, M., \& Haerudin. (2021). Analisis Kemampuan Berpikir Kreatif Matematis Siswa Kelas VIII SMP pada Materi Statistika. MAJU: Jurnal Ilmiah Pendidikan Matematika, 8(1), 233-243.

Hidayanti, D., As'ari, A. R., \& Daniel, T. (2016). Analisis kemampuan berpikir kritis siswa smp kelas IX pada materi kesebangunan. Konferensi Nasional Penelitian Matematika Dan Pembelajarannya (KNPMP I) Universitas Muhammadiyah Surakarta, 12 Maret 2016, 2502-6526(Knpmp I), 276-285.

Kharisma, E. N. (2018). Analisis Kemampuan Berpikir Kritis Matematis Siswa SMK pada Materi Barisan dan Deret. Jurnal Review Pembelajaran Matematika, 3(1), 62-75. https://doi.org/https://doi.org/10.15642/jrpm.2018.3.1.62-75

Kodu, H. I., MUzaki, A., \& Wahyudi, E. (2019). Analisis Kemampuan Berpikir Kritis Siswa Kelas IX di SMP Swasta Rangga Rame pada Materi Statistika Tahun Ajaran 2019/2020. Jurnal Penelitian Pendidikan Matematika Sumba, 2(1), 111-119.

Noordyana, M. A. (2016). Meningkatkan Kemampuan Berpikir Kritis Matematis Siswa melalui Pendekatan Metacognitive Instruction. Mosharafa: Jurnal Pendidikan Matematika, 5(2), 120-127. https://doi.org/10.31980/mosharafa.v5i2.267

Nugroho, D. (2017). Analisis Berpikir Kritis Matematika Siswa Kelas VII Ditinjan Dari Tipe Kepribadian Big Five dalam Setting Problem Based Learning. Universitas Negeri Semarang.

Peter, E. E. (2012). Critical Thinking: Essence for Teachiing Mathematics and Mathematics Problem Solving Skill. African Journal of Mathematics and Computer Science Research, 5(3), 39-43. https://doi.org/https://doi.org/10.5897/AJMCSR11.161

Purmawidyani, M. (2017). Pembelajaran matematika menggunakan pendekatan problem based learning untuk meningkatkan kemampuan berpikir kritis matematis siswa SMP. Skripsi tidak dipublikasikan. Bandung: Program Studi Pendidikan Matematika, STKIP Siliwangi

Rachmawati, V. (2019). Pengaruh Video Pembelajaran di Pendabuluan Pembelajaran Statistika dan Peluang dengan Model Pembelajaran Problem Based Learning terbadap Kemampuan Berpikir Kritis dan Sikap Matematika [Universitas Negeri Yogyakarta]. http://eprints.uny.ac.id/id/eprint/66170

Rahma, S., Farida, F., \& Suherman, S. (2017). Analisis berpikir kritis siswa dengan pembelajaran socrates kontekstual di SMP negeri 1 padangratu lampung tengah. Prosiding Seminar Nasional Matematika Dan Pendidikan Matematika, $1(1), \quad 121-128$. http://ejournal.radenintan.ac.id/index.php/pspm/article/view/1038

Sari, M., Susiswo, \& Nusantara, T. (2016). Analisis Kemampuan Berpikir Kritis Siswa Kelas Viii-D Smp Negeri 1 Gambut. Prosiding Seminar Nasional Pendidikan Matematika, 1(November), 254-264.

Snyder, Gueldenzoph, L., Snyder, \& J, M. (2008). Teaching Critical Thinking and Problem Solving Skills. Delta Pi Epsilon Journal, 10. 
Tresnawati, T., Hidayat, W., \& Rohaeti, E. E. (2017). Kemampuan Berpikir Kritis Matematis Dan Kepercayaan Diri Siswa Sma. Symmetry: Pasundan Journal of Research in Mathematics Learning and Education, 2, 116-122. https://doi.org/http://dx.doi.org/10.23969/symmetry.v2i2.616

Warniasih, K., Kurniawati, R. M., \& Utami, N. W. (2019). Analisis Kemampuan Berpikir Kritis Matematis Siswa Smp Melalui Pembelajaran Inkuiri. Journal of Honai Math, 2(2), $103-116$. https://doi.org/10.30862/ihm.v2i2.68

Widiantari, N. K. M. P., Suarjana, I. M., \& Kusmariyatni, N. (2016). Analisis Kemampuan Berpikir Kritis Siswa Kelas Iv Dalam Pembelajaran Matematika. Journal PGSD Pendidikan Ganesha, 4(1), 1-3.

Wijaya, T. T., Dewi, N. S. S., Fauziah, I. R., \& Afrilianto, M. (2018). Analisis Kemampuan Pemahaman Matematis Siswa Kelas IX Pada Materi Bangun Ruang. UNION: Jurnal Ilmiah Pendidikan Matematika, 6(1), 19-28. https://doi.org/10.30738/.v6i1.2076

Yunita, N., Rosyana, T., \& Hendriana, H. (2018). Analisis Kemampuan Berpikir Kritis Matematis Berdasarkan Motivasi Belajar Matematis Siswa Smp. JPMI (Jurnal Pembelajaran Matematika Inovatif), 1(3), 325. https://doi.org/10.22460/jpmi.v1i3.p325-332 